\begin{tabular}{|l|l|l||}
\hline \multicolumn{2}{|c|}{ PublisherInfo } \\
\hline \hline PublisherName & $:$ & Palgrave Macmillan UK \\
\hline \hline PublisherLocation & $:$ & London \\
\hline \hline PublisherImprintName & $:$ & Palgrave Macmillan \\
\hline \hline
\end{tabular}

\title{
Linking ASHE and LFS: can the main earnings sources be reconciled?
}

\begin{tabular}{|l|l|l||}
\hline \multicolumn{2}{|c||}{ ArticleInfo } \\
\hline \hline ArticleDOI & $:$ & $10.1057 /$ palgrave.elmr.1410041 \\
\hline \hline ArticleCategory & $:$ & Feature \\
\hline \hline ArticleFirstPage & $:$ & 24 \\
\hline \hline ArticleLastPage & $:$ & 31 \\
\hline \hline & $:$ & RegistrationDate $:$ 2007-3-16 \\
ArticleHistory & $:$ & OnlineDate $\quad 2007-3-16$ \\
\hline ArticleCopyright & $:$ & Crown copyright2007 \\
\hline \hline
\end{tabular}




\section{Catrin Ormerod, ${ }^{\text {Affl }}$}

Felix Ritchie, ${ }^{\text {Affl }}$

\section{Describes a project to link and study ASHE and the LFS, examining differences between earnings and hours information collected.}

This article describes a project to link and study the Annual Survey of Hours and Earnings and Labour Force Survey. Thisinvestigation looked at the differences between the earnings and hours information collected on the surveys. Theresults show that some perceptions over the accuracy of the surveys are misplaced, and that researchers can have moreconfidence in using the data.

The Full Text of this article can be found on the National Statistics website (http://www.statistics.gov.uk/elmr/03_07/downloads/ELMR03_07Ormerod_Ritchie.pdf). 